\title{
Transparency and Monetary Affairs
}

Kaufmann, Christine ; Weber, Rolf H

DOI: https://doi.org/10.1017/CBO9781107479920

Posted at the Zurich Open Repository and Archive, University of Zurich

ZORA URL: https://doi.org/10.5167/uzh-102412

Book Section

Originally published at:

Kaufmann, Christine; Weber, Rolf H (2014). Transparency and Monetary Affairs. In: Cottier, Thomas; et al. The Rule of Law in Monetary Affairs: World Trade Forum. Cambridge, UK: Cambridge University Press, 462-489.

DOI: https://doi.org/10.1017/CBO9781107479920 


\section{Cambridge Books Online}

\section{http://ebooks.cambridge.org/}

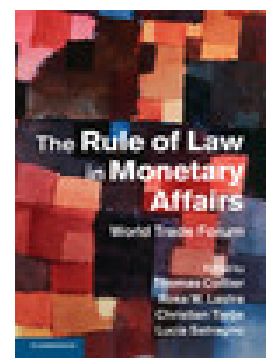

The Rule of Law in Monetary Affairs

World Trade Forum

by Thomas Cottier, Rosa M. Lastra, Christian Tietje, Edited in association with Lucia Sa

Book DOI: http://dx.doi.org/10.1017/CBO9781107479920

Online ISBN: 9781107479920

Hardback ISBN: 9781107063631

Paperback ISBN: 9781107687622

\section{Chapter}

18 - Transparency and monetary affairs pp. 462-489

Chapter DOI: http://dx.doi.org/10.1017/CBO9781107479920.023

Cambridge University Press 


\title{
Transparency and monetary affairs
}

\author{
CHRISTINE KAUFMANN AND ROLF H. WEBER
}

\section{A. Introduction}

Transparency has for decades been a hotly debated topic in financial markets. In the aftermath of the financial crisis the transparency debate became a priority for politicians and regulators around the world. A hundred years ago, Supreme Court Justice Louis Brandeis expressed his concern about the lack of transparency in financial markets, mainly in view of the necessity to protect investors better: 'Publicity is justly commended as a remedy for social and industrial diseases. Sunlight is said to be the best of disinfectants; electric light the most efficient policeman'. ${ }^{1}$

According to the Oxford English Dictionary, transparency means 'easily seen through, recognized, understood, or detected; manifest, evident, obvious, clear'. ${ }^{2}$ Transparency in government is to be realised by dissemination of information, both as a human right (in the form of freedom of information) and by making information public through institutional channels. ${ }^{3}$ From an economic perspective, the availability of adequate information is a prerequisite for efficient free markets. ${ }^{4}$ Therefore, the transparency principle encompasses the element of visibility and clarity on the one hand and the element of empowerment and capability on the other, entailing the process of 'seeing through' as well as the 'object' that is being looked at. ${ }^{5}$

${ }^{1}$ L. D. Brandeis, 'What Publicity Can Do' in L. D. Brandeis (ed.), Other People's Money: And How the Bankers Use It (Mansfield Centre, CT: Martino Publishing, 2009, first published 1914 by McClure Publications), p. 92.

2 Oxford English Dictionary, online edition, 2012, www.oed.com/view/Entry/204968? redirectedFrom $=$ transparency\# eid.

${ }^{3}$ R. H. Weber, Datenschutz v. Öffentlichkeitsprinzip, (Zurich: Schulthess, 2010), paras. 18 and 24 .

${ }^{4}$ G. A. Akerlof, 'The Market for Lemons: Quality Uncertainty and the Market Mechanism', Quarterly Journal of Economics 84 (1970), 488.

5 See C. Kaufmann and R.H. Weber, 'The Role of Transparency in Financial Regulation', Journal of International Economic Law 13:3 (2010), 779-97, 779-80 with further references. 
We developed a comprehensive, rule-based rather than purely process-oriented approach by suggesting a three-dimensional concept of transparency in financial markets. ${ }^{6}$ This three-dimensional concept, upon which we can build, is summarised as follows:

- The first pillar is designed by institutional aspects, i.e., procedures and decision-making; by providing legal certainty, transparency can serve as an anchor for financial regulation.

- The second pillar encompasses the substantive backbone of financial regulation addressing the values and goals of financial market policies.

- The third pillar looks at the accountability of actors as an essential element for rebuilding confidence in the financial market system.

Transparency takes different shapes for different actors and different segments in financial markets. While transparency for commercial transactions and private actors has received substantial attention in legal discussions, legal research on the role of transparency in monetary affairs is still in its infancy. For a long time, central banks, as the key actors in monetary affairs, worked secretly, and 'a change in bank rate was no more regarded as the business of the Treasury than the color which the Bank [of England] painted its front door. ${ }^{7}$ Even in 1989, a book on the Federal Reserve with the catchy title Secrets of the Temple seemed to realistically reflect central banks' policies. ${ }^{8}$ Clearly, these days are over. Central banks are now supposed to be open about their objectives, outlooks, policy strategies and even their mistakes. ${ }^{9}$ This is particularly relevant for transactions that require confidentiality in order to be effective, such as market interventions with a view to influencing exchange rates. However, such transactions are not completely exempt from transparency requirements, yet they need to be communicated $e x$ post rather than in advance. Recent central bank regulations take these considerations into account by, e.g., publishing the minutes of monetary

${ }^{6}$ Ibid., $783 \mathrm{ff}$.

7 Otto Niemeyer, director of financial inquiries at HM Treasury commenting on British monetary policy in 1929, quoted in: D. E. Moggridge, British Monetary Policy, 1924-1931 (Cambridge University Press, 1972), p. 160.

${ }^{8}$ W. Greider, Secrets of the Temple: How the Federal Reserve Runs the Country (New York: Touchstone, 1989).

9 N. Dincer and B. Eichengreen, 'Central Bank Transparency: Causes, Consequences and Updates', Theoretical Inquiries in Law 11 (2010), 75-123, 76. 
authorities' meetings with a certain time delay ${ }^{10}$ or requiring a central bank's governors to explain their past monetary policy decisions before parliamentary commissions. ${ }^{11}$ Ex post transparency may therefore partially compensate for the lack of government or parliament involvement when urgent market interventions require confidentiality.

This chapter applies the above mentioned three-dimensional concept of transparency to monetary affairs as a key segment of financial markets.

\section{B. Monetary affairs: mapping existing actors and their activities}

Transparency in general has been a priority on the agenda of governments for a long time. When President Obama announced his initiative for open government in $2009,{ }^{12}$ he was able to build on a commonly accepted but not very specific principle of a democratic government required to be transparent while leaving room for the protection of essential state and security interests. This kind of balance, so far, has not been applied to monetary affairs. In fact the question is twofold: to what extent is transparency functionally possible and when does its operation depend upon confidentiality vis-à-vis governments and financial markets?

Since monetary affairs are neither a homogeneous field nor are they conducted by a single actor, a brief mapping of existing actors and their activities in this area is necessary. Apart from governments, monetary authorities, i.e., central banks and currency boards, are the key actors. ${ }^{13}$

${ }^{10}$ E.g. for the US Federal Reserve, see Sec. 10.10 of the Federal Reserve Act (12 USC 226) and the Government in the Sunshine Act (5 USC section 552b) and the Federal Reserve Board's Rules Regarding Public Observation of Meetings (12 CFR part 261b). The Governing Board of the ECB is currently (2013) considering to publish the minutes of its meeting: joint interview with Benoît Cœuré and Jörg Asmussen, Members of the Executive Board of the ECB, conducted by Andrea Rexer and Jean-Pierre Robin on 23 July 2013 and published on 29 July 2013 in Süddeutsche Zeitung and Le Figaro (www.ecb. europa.eu/press/key/date/2013/html/sp130729.en.html).

11 Article 7 para. 2 Federal Act of the Swiss National Bank (SR 951.11).

12 Transparency and Open Government, Presidential Memorandum for the Heads of Executive Departments and Agencies, 74 FR 4685, 21 January 2009.

13 C. E. Walsh, Monetary Theory and Policy, 3rd edn (Cambridge, MA: Massachusetts Institute of Technology Press, 2010), pp. 135-43. 


\section{Governments}

Many governments issued 'sunshine laws ${ }^{14}$ with Sweden taking the lead as early as $1766,{ }^{15}$ followed, inter alia, by the US with the Freedom of Information Act of $1966 .{ }^{16}$ The starting point for government transparency is the normative concept of a right to know as a key prerequisite for democracy and participation. This general concept has only recently been further refined to support specific public policies such as the protection of the environment, ${ }^{17}$ or fiscal and budget policy. ${ }^{18}$ Thus, the normative concept is increasingly being complemented by substantive criteria on how specific policy goals can be enhanced by transparency. ${ }^{19}$ The way in which transparency mechanisms are structured shapes their impact on public policy - on effectiveness on equity and on democratic accountability. ${ }^{20}$

Clearly, governmental activities have an impact on monetary affairs. Of particular relevance are fiscal and monetary policy measures. Often, the administration will take the lead in fiscal policy with a monetary authority - a central bank or a currency board ${ }^{21}$ - being the main responsible institution for the monetary policy. Ideally, fiscal policy and monetary policy are complementary. However, a fiscal policy which does not factor in existing budget constraints may destabilise long-term inflation expectations and thus lead to increased macroeconomic instability. ${ }^{22}$ Transparency can play an important role in

14 Thus taking up Justice Brandeis' metaphor, Brandeis, 'What Publicity Can Do'. See for example the Swiss Freedom of Information Act of 2004 (SR 152.3).

${ }^{15}$ His Majesty's Gracious Ordinance Relating to Freedom of Writing and of the Press, 2 December 1766, English version in: J. Mustonen (ed.), The World's First Freedom of Information Act - Anders Chydenius' Legacy Today (Kokkola: Anders Chydenius Foundation 2006), pp. 8-17. The current version is the Public Access to Information of 2009, as amended in 2013 (Offentlighets- och sekretessförordning, 2009:641).

16 The Freedom of Information Act, 5 USC $\$ 552$, as amended by Public Law No. 104-231, 110 Stat. 3048.

17 The most prominent example is the Aarhus Convention on Access to Information, Public participation in Decision-Making and Access to Justice in Environmental Matters of 25 June 1998 (UN Treaty Series vol. 2161, 447); A.P. J. Mol, 'The Future of Transparency: Power, Pitfalls and Promises', Global Environmental Politics 10:3 (2010), 132-43.

18 D. Heald, 'Why is Transparency about Public Expenditure so Elusive?', International Review of Administrative Sciences 78:1 (2012), 30-49.

19 Mol, 'The Future of Transparency', 132.

${ }^{20}$ Heald, 'Why is Transparency about Public Expenditure so Elusive?', 32.

${ }^{21}$ Discussed in Section B.II.2.

22 S. Kirchner, 'Reforming Fiscal Responsibility Legislation', Economic Papers 30:1 (2011), 29-32, 29; P. de Renzo and H. Masud, 'Measuring and Promoting Budget Transparency: 
reconciling different policies and fostering predictability and legal certainty. In addition, in the light of increasing international connectedness, transparency is seen as a prerequisite for a modern concept of fiscal sovereignty in a globalised environment. ${ }^{23}$

These normative elements are fairly straightforward. What needs to be further developed in a monetary context, however, are specific transparency mechanisms to foster policy coherence as well as fiscal sovereignty. In order to partially fill this gap, the International Monetary Fund (IMF) developed specific standards for fiscal transparency, as discussed in Section C.

\section{Monetary institutions}

One of the major challenges in designing monetary institutions is the uncertainty about future social decisions. This uncertainty is due to both the impossibility and the undesirability of committing future monetary policy-makers to a previously defined strategy. An ideal framework would implement what is currently believed to be the optimal strategy and only deviate from it if there is a collective change of view on this strategy. ${ }^{24}$ As Mervyn King put it so aptly, 'our ignorance is too pervasive to allow the adoption of a rule of how learning should occur.,25

\section{Central banks}

From an institutional perspective, with a few exceptions, central banks are rather 'youthful'. ${ }^{26}$ It is therefore not surprising that the debate on central bank governance, including transparency, is relatively recent. Accordingly, new studies show a clear trend towards greater central bank transparency. ${ }^{27}$ Yet, a caveat applies: most of these studies are based on a selective set of indicators for transparency, such as the publication of inflation targets. ${ }^{28}$ Apart from this lack of conceptual rigour, the economic context in which a central bank operates, whether it is situated in an emerging or a developed country, is not always taken

The Open Budget Index as a Research and Advocacy Tool', Governance: An International Journal of Policy, Administration, and Institutions 24:3 (2011), 607-16, 608.

${ }^{23}$ P. Dietsch, 'Rethinking Sovereignty in International Fiscal Policy', Review of International Studies 37 (2011), 2107-20, 2117-18.

${ }^{24}$ M. King, 'The Institutions of Monetary Policy', Richard T. Ely Lecture, American Economic Association Proceedings 94:2 (2004), 1-13, 1 and 5.

${ }^{25}$ Ibid., $5 .{ }^{26}$ Ibid., 2.

27 Dincer and Eichengreen, 'Central Bank Transparency', 91.

${ }^{28}$ For a critical and more comprehensive approach, ibid., 88-9. 
into account. This empirical finding has been interpreted in various ways. One view is that transparency enhances the effectiveness of monetary policy because it allows for better communication and clearer expectations among market participants. Central bank transparency thus relates to three aspects: its price stability commitment, policy intentions and effective communication of its economic assessment. ${ }^{29}$ Managing expectations, especially concerning inflation, is an essential element in order for monetary policy to affect outcomes. ${ }^{30}$ Based on this rationale, the Governing Council of the European Central Bank announced its committment to give forward guidance to market participants by communicating its specific expectations on market developments. ${ }^{31}$

Another view relates central bank transparency to democratic accountability. Transparency is therefore seen as a mechanism to balance central bank independence. ${ }^{32}$ From an economic perspective, transparency ensures accountability of policy-makers in an environment where the traditional instruments of fixed or pegged exchange rates and close central bank supervision by the government are replaced by flexible exchange rates and independence of central banks. ${ }^{33}$

The democratic rationale for implementing transparency and accountability measures played a major role when European central banks became independent in the context of the Treaty of Maastricht in 1992, and the establishment of the European Monetary Union. While the design of the new European Central Bank, to a large extent, followed the model of the independent German Bundesbank, other central banks such as the Bank de France were still under close supervision of the government at the time. Studies on data from the 1980s suggested that independence of the central bank was one of the key elements for success in maintaining price stability. ${ }^{34}$ Prime examples at the time were the

${ }^{29}$ M. K. Tang and X. Yu, 'Communication of Central Bank Thinking and Inflation Dynamics', IMF Working Paper WP/11/209 (2011), pp. 6-7.

${ }^{30}$ M. Ehrmann, S. Eijffinger and M. Fratzscher, 'The Role of Central Bank Transparency for Guiding Private Sector Forecasts', European Central Bank, Working Paper Series No. 1146 (January 2010).

31 Press conference of the European Central Bank, Introductory statement by Mario Draghi, President of the ECB, Frankfurt am Main, 4 July 2013.

32 Dincer and Eichengreen, 'Central Bank Transparency', 77.

${ }^{33}$ S. C. W. Eijffinger and P. M. Geraats, 'How Transparent are Central Banks?', European Journal of Political Economy 22 (2006), 1-21.

34 A. Cukierman, S. Webb and B. Neyapti, 'Measuring the Independence of Central Banks and its Effect on Policy Outcomes', The World Bank Economic Review 6 (1992), 353-98; 
German Bundesbank and the Federal Reserve. More recent studies confirmed that greater central bank independence is associated with lower inflation. ${ }^{35}$ In addition, there is evidence that greater transparency is associated with more use of public information and, in particular, central banks' forecasts. In such a context, the private sector will make greater use of information provided by the central bank. ${ }^{36}$ If the public is better informed about monetary policy, it can react more quickly to policy decisions and thereby prevent public authorities from manipulating inflation in pursuit of other interests. ${ }^{37}$

\section{Currency boards}

Unlike central banks, currency boards are bound by rules that generally do not allow for discretionary monetary policy decisions. Typically, they will apply a fixed exchange rate with a reserve currency. As a result, conflicts between exchange rate policies and monetary policies are unlikely. Since currency boards are increasingly seen as an instrument for overcoming central banks' inherent lack of transparency, a brief critical review seems appropriate.

Although currency boards performed well until the 1930s, they were to a large extent replaced by central banks after World War II. In the 1990s, currency boards became relevant again. The reason for this unexpected revival was the desire to install a monetary regime to which the fiscal regime would be subordinate. In other words, currency boards were seen as means to impose fiscal discipline. ${ }^{38}$

The most prominent current example of a currency board is the Hong Kong Monetary Authority (HKMA). Hong Kong applies a linked exchange rate, with the Hong Kong dollar being linked to the US dollar at an exchange rate of 7.8 Hong Kong dollars to one US dollar. Typically, for a currency board system, the monetary base is fully backed by foreign currency reserves at this fixed exchange rate. The Basic Law for Hong Kong explicitly requires that the issue of Hong Kong dollars is backed by

A. Cukierman, Central Bank Strategy, Credibility and Independence - Theory and Evidence (Cambridge, MA: The MIT Press, 1992); for an update A. Cukierman, 'Central Bank Independence and Monetary Policymaking Institutions - Past, Present and Future', European Journal of Political Economy 24 (2008), 722-36.

35 C. Crowe and E. E. Meade, 'Central Bank Independence and Transparency: Evolution and Effectiveness', European Journal of Political Economy 24 (2008), 763-77, 769-70.

${ }^{36}$ Ibid., 771-2. ${ }^{37}$ Dincer and Eichengreen, 'Central Bank Transparency', 88.

${ }^{38}$ S. H. Hanke, 'Currency Boards', Annals, American Academy of Political and Social Science 579 (2002), 87-105, 99. 
a 100 per cent reserve fund..$^{39}$ However, the fact that the mandate of a currency board and the objectives of monetary policy are built on legally binding rules does not automatically provide transparency, as the development of the Hong Kong Exchange Fund illustrates: established by ordinance in 1935, the accounts of the Exchange Fund were kept confidential until 1992. Since then, transparency has been steadily increased; since 1999 the Special Data Dissemination Standard (SDDS) of the International Monetary Fund ${ }^{40}$ has been applied. In 2000 a new template for international and foreign currency liquidity was implemented:

The public disclosure of such information on a timely and accurate basis promotes informed decision making in the public and private sectors, thereby helping to improve the functioning of global financial markets. ${ }^{41}$

Currently, the templates are published monthly. In addition, the record of discussion of the Exchange Fund Advisory Committee (EFAC) SubCommittee on Currency Board Operations is disclosed to the public.

On its website, the HKMA identifies five characteristics of a properly run currency board: transparency, simplicity, reliability, predictability and credibility. ${ }^{42}$ These characteristics are however not currency-board specific but rather seem to reflect what is currently understood as effective public policy-making. Similarly, HKMA's published statement on transparency remains rather general:

The HKMA seeks to follow international best practices in its transparency arrangements. The HKMA places great emphasis on promoting a wide understanding of its policies and work. This is done through extensive contacts with the media, a range of regular publications, a comprehensive website, a public enquiries service and an educational programme. ${ }^{43}$

39

Article 111 of the Basic Law for the Hong Kong Special Administrative Region: 'The Hong Kong dollar, as the legal tender in the Hong Kong Special Administrative Region, shall continue to circulate. The authority to issue Hong Kong currency shall be vested in the Government of the Hong Kong Special Administrative Region. The issue of Hong Kong currency must be backed by a 100 per cent reserve fund. The system regarding the issue of Hong Kong currency and the reserve fund system shall be prescribed by law.'

${ }^{41}$ www.hkma.gov.hk/eng/key-functions/exchange-fund/transparency.shtml.

42 www.hkma.gov.hk/eng/classroom/page/work/work_02_01.htm.

43 www.hkma.gov.hk/eng/classroom/page/work/work_06_01.htm. 
In sum, the classic blueprint of a currency board ${ }^{44}$ which would emphasise its transparency in contrast to traditional central banks' secrecy cannot be applied to the new generation of currency boards which was introduced in the 1990s. These days, currency boards are still based on the rather mechanical principle of conversion and issuing fully backed base money. Yet, guaranteeing convertibility throughout a highly complex international financial system has become challenging. Due to the backing requirement, a currency board has limited possibilities for providing additional liquidity in times of systemic constraints. ${ }^{45}$ As a result, stable monetary policy may come at the price of increased systemic risks. For this reason, most modern currency boards have applied specific policies in this regard and for example also serve as lender of last resort. ${ }^{46}$ Not surprisingly, these policies require a clear division of tasks between the different actors and therefore call for transparency.

\section{Transparency and the financial crisis}

\section{Lack of transparency as an underlying reason for the financial crisis}

\section{Financial markets}

While the reasons for the recent financial crisis are manifold, a lack of transparency played a major role in undermining predictability of and trust in the financial markets and in the resulting volatility and instability. Intransparency may occur in three dimensions: product, governance and organisation related.

Newly developed structured financial products such as collateralised debt obligations (CDOS) were highly complex by nature and inherently intransparent. ${ }^{47}$ Tools and instruments designed to hedge risks were sometimes (mis)used for increased leverage and, in the words of

${ }^{44}$ C. Ho, 'A Survey of the Institutional and Operational Aspects of Modern-day Currency Boards', Bank for International Settlements (BIS) Working Papers No 110 (March 2002), pp. 3-5.

45 Ibid., p. 13.

${ }^{46}$ Ibid., p. 15. Hanke, 'Currency Boards', seems to have overlooked this development, at 100 .

47 J. Crotty, 'Structural Causes of the Global Financial Crisis: A Critical Assessment of the 'New Financial Architecture", Cambridge Journal of Economics 33 (2009) 563-80, at 566. 
Warren Buffet, became 'a weapon of financial mass destruction'. ${ }^{8}$ Moreover, many financial innovations created links between formerly unconnected players as illustrated, for instance, by the US subprime crisis. $^{49}$

New synthetic products and the related increase in interconnectivity among financial markets call for a governance reaction in the form of effective risk management systems both within institutions and at the government level. Hence, in many financial institutions the real financial exposure was not detected due to the lack of an effective risk management system. The abuse of economic models to build up derivative positions in order to profit from high returns, as long as the correlating risks did not materialise, had not been anticipated and accordingly was not reflected in the risk management systems available. A similar phenomenon could be observed at the state level: supervisory authorities and regulators failed to react and instead continued to rely on mathematical rigour and numerical precision in risk management and asset pricing tools. In particular, the Basel II Framework with its highly sophisticated risk assessment model ${ }^{50}$ contributed to a certain information overload, which instead of promoting transparency led to opacity, ${ }^{51}$ and eventually a control illusion. ${ }^{52}$

The financial crisis showed that financial groups and financial conglomerates can threaten the stability of the financial system. One of the reasons why these risks had not been detected earlier was the mix of regulated and unregulated entities (such as special purpose entities and unregulated holding companies) across sectorial boundaries and the related challenges for sector-specific supervisory oversight. A prime example in this respect was American International Group Ltd (AIG), the world's largest insurance company. AIG's problems stemmed from two main sources: its securities lending programme and its investment in 'The Financial Crisis and the Systemic Failure of the Economics Profession', Critical Review 21:2-3 (2009), 249-67, 254.

49 Ibid., 263.

50 Bank of International Settlements, Basel II: International Convergence of Capital Measurement and Capital Standards: A Revised Framework - Comprehensive Version, June 2006: www.bis.org/publ/bcbs128.htm.

51 C. M. Bradley, 'Transparency is the New Opacity: Constructing Financial Regulation after the Crisis', American University Business Law Review 1 (2011) 7-34, 32.

52 Colander et al., 'The Financial Crisis', 254. 
credit default swaps (CDSs). ${ }^{53}$ Despite its systemic relevance, AIG was, at the time, under the supervision not of the Federal Reserve Bank but of the Office of Thrift Supervision (OTS). OTS was the consolidated supervisor of AIG because it was considered a thrift holding company by virtue of its ownership of the AIG Federal Savings Bank. Given AIG's involvement in both financial and non-financial entities, consolidated supervision was not possible and systemic risks remained unidentified until autumn 2008 when AIG was on the verge of collapsing and was eventually bailed out by the Federal Reserve. One of the key lessons learnt from the financial crisis was therefore that it was necessary to strengthen consolidated supervision particularly for systemically relevant institutions with cross-sectorial activities. ${ }^{54}$

Finally, another phenomenon which has so far not attracted much attention is closely linked to the above-mentioned organisational and governance-related risks. As just noted in the context of the AIG, actors in financial markets which are not licensed as banks or securities dealers have become increasingly important. Such 'shadow-banking ${ }^{55}$ activities may create opportunities but at the same time become a source of risks. Since they are not covered by the traditional financial governance mechanisms and may therefore lack adequate regulatory frameworks and monitoring, problems may amount to systemic risks, especially when such institutions are performing bank-like functions such as leverage and when they are strongly connected with the banking system. It is therefore necessary for monetary and supervisory authorities to first map existing actors and then to identify and assess potential risks. ${ }^{56}$

\section{Intransparent financial markets and monetary affairs}

With risks in financial markets accumulating into systemic risks, monetary authorities and political bodies became involved in crisis management. In addition to insufficient information about the risk exposure of individual financial institutions, uncertainty about how monetary

53 United States Government Accountability Office (GAO), Report to Congressional Requesters: Review of Federal Reserve System Financial Assistance to American International Group, Inc, GAO-11-616, (September 2011), p. 5.

54 Basel Committee on Banking Supervision, Joint Forum, Principles for the Supervision of Financial Conglomerates (Basel: Bank for International Settlements, September 2012).

55 Defined by the Financial Stability Board as 'credit intermediation involving entities and activities outside the regular banking system', Global Shadow Banking Monitoring Report 2012, 18 November 2012, p. 3.

${ }^{56}$ Ibid., p. 6. 
authorities and political institutions intended to react exacerbated the crisis. Clearly, poorly understood and unknown risks can barely be addressed in monetary policy. Not surprisingly, transparency has become a regularly debated topic during the last four years. The following section outlines some of the relevant policy discussions.

\section{Reactions in policy making}

The most noteworthy efforts to improve transparency are mirrored in the G-20 declarations and statements, but other organisations have also addressed transparency issues.

\section{1. $\mathrm{G}-20$}

While decision-making in the G-20 itself cannot be defined as transparent and the group is not inclusive with regard to its stakeholders, ${ }^{57}$ the 'transparency discourse' has appeared at different levels of intensity at several of the seven G-20 summits held so far:

(i) Transparency was most prominently mentioned at the G-20 Summit in Washington (November 2008). ${ }^{58}$ The first of the five common principles for reform of financial markets addressed the strengthening of transparency and accountability. Transparency is also mentioned in the third common principle on the promotion of integrity in financial markets as well as in the list of the tasks of ministers and experts, requesting them to make efforts to strengthen the resilience and transparency of credit derivatives markets.

In the Action Plan for the implementation of the principles for reform, the word 'transparency' is again mentioned three times, among others in the section on prudential oversight.

57 R. H. Weber, 'The Legitimacy of the G20 as a Global Financial Regulator', Banking \& Finance Law Review 28 (2013) 389-407. C. Kaufmann, 'International Law in Recession? The Role of International Law when Crisis Hits: Food, Finance, and Climate Change', in U. Fastenrath, R. Geiger, D.-E. Khan, A. Paulus, S. von Schorlemer and C. Vedder (eds.), From Bilateralism to Community Interest, Essays in Honour of Bruno Simma (Oxford University Press, 2011), pp. 1189-206, 1202-3. M. Giovanoli, 'The International Monetary and Financial Architecture: Some Institutional Aspects', Chapter 3, this volume.

58 See Declaration G-20 Leaders Summit, Washington 2008: www.g20.utoronto.ca/2008/ 2008declaration 1115.html. 
(ii) The G-20 Summit in London (April 2009) ${ }^{59}$ addressed transparency in the context of the strengthening of financial supervision and regulation, since transparency contributes to the restoration of confidence and the rebuilding of trust in the financial system.

(iii) The Declaration of the G-20 of the Pittsburgh Summit (September $2009)^{60}$ mentions the word 'transparency' thirteen times in manifold contexts. Without going into the details of the various regulatory topics, two aspects are noteworthy:

- The G-20 welcomes the expansion of the Global Forum on Transparency and Exchange Information, including the participation of developing countries, as well as the agreement to deliver an effective programme of peer review. ${ }^{61}$

- The G-20 supports the voluntary participation in the Extractive Industries Transparency Initiative, which calls for regular public disclosure of certain payments. ${ }^{62}$

(iv) In the Declaration of the Toronto Summit (June 2010), ${ }^{63}$ the G-20 particularly addressed transparency in the context of financial sector reform including aspects of banks' balance sheets. Again the word 'transparency' is mentioned more than ten times. The following Seoul Summit of November 2010 did not specifically look into these issues.

(v) The Cannes Summit of the G-20 (November 2011) ${ }^{64}$ partly changed the perspective of the political agenda; transparency in this declaration is related to agricultural markets, energy markets and trade relations.

(vi) The Declaration of the G-20 leaders of the Los Cabos Summit (June $2012)^{65}$ shows a two-sided picture: transparency was looked at from the angle of financial sector reform on the one hand and from the perspective of markets for agricultural products and energy, among others, on the other hand. Apart from general elements of

59 See Declaration G-20 Leaders Summit, London 2009: www.g20.utoronto.ca/2009/ 2009communique0402.html.

${ }^{60}$ See Declaration G-20 Leaders Summit, Pittsburgh 2009: www.g20.utoronto.ca/2009/ 2009communique0925.html.

${ }^{61}$ Ibid., No. $15 .{ }^{62}$ Ibid., No. 42.

63 See Declaration G-20 Leaders Summit, Toronto 2010: www.g20.utoronto.ca/2010/ to-communique.html.

${ }^{64}$ See Declaration G-20 Leaders Summit, Cannes 2011: www.g20.utoronto.ca/2011/ 2011-cannes-communique-111104-en.html.

65 See Declaration G-20 Leaders Summit, Los Cabos (Mexico) 2010: www.g20.utoronto.ca/ 2012/2012-0619-loscabos.html. 
transparency and accountability leading to greater credibility and confidence, as well as to improved surveillance (including the strengthening of competition among credit rating agencies), transparency of the exchange rate policy as a part of monetary law is explicitly mentioned (related to the renminbi exchange rate regime).

\section{International Monetary Fund}

In relation to its monetary stability objectives, the International Monetary Fund (IMF), together with the Bank for International Settlements (BIS), published a 'Code of Good Practices in Transparency in Monetary and Financial Policies (MFP Transparency Code). As a general rule, the MFP Transparency Code calls on the central bank of each country as the institution responsible for conducting monetary policy' ${ }^{66}$ The MFP Transparency Code addresses the clarity of roles, responsibilities and objectives (Part I), the open process for monetary policy decisions (Part II), the public availability of information on monetary policy (Part III), and the accountability and assurance of integrity by the Central Bank (Part IV). ${ }^{67}$ Each section contains additional rules and guidelines. ${ }^{68}$ Based on the MFP Transparency Code, the IMF encourages the authorities of member states to participate in a detailed assessment of transparency of monetary and financial policies, mainly in the context of their participation in the Financial Sector Assessment Program (FSAP); an FSAP evaluation entails detailed principle-by-principle assessments which are condensed in the Reports on the Observance of Standards and Codes (ROSC). ${ }^{69}$

In relation to fiscal matters, the IMF developed a 'Code of Good Practices on Fiscal Transparency', 70 a 'Manual on Fiscal Transparency', and a 'Guide on Resource Revenue Transparency'. The Code is based on four general pillars, namely clarity of roles and responsibilities (Part I), open budget processes (Part II), public availability of information (Part III), and assurances of integrity (Part IV). The implementation of

${ }^{66}$ IMF, Code of Good Practices in Transparency in Monetary and Financial Policies (July 1999), p. 18.

${ }^{67}$ See also R. H. Weber, 'Financial Stability - Structural Framework and Development Issues', International and Comparative Corporate Law Journal 6 (2008), 1-19, 1 and 7.

${ }^{68}$ For further details, see D. W. Arner, Financial Stability, Economic Growth, and the Role of Law (Cambridge University Press, 2007), p. 131.

69 R.H. Weber and D.W. Arner, 'Toward a New Design for International Financial Regulation', University of Pennsylvania Journal of International Law 29 (2007), 391453, $417 \mathrm{ff}$.

70 IMF, Code of Good Practices on Financial Transparency of 1998, updated 2007. 
the Code should follow the 'Manual' and the 'Guide'; the assessment of compliance with the Code can also be done in the context of the establishment of ROSC.

Another important aspect is the transparency of macroeconomic data since its public availability and comparability is important in combating financial crises. ${ }^{71}$ As an instrument designed to provide guidance, the IMF has published standards in relation to data dissemination and compilation, such as the Special Data Dissemination Standard $(\text { SDDS })^{72}$ and the General Data Dissemination System (GDDS). ${ }^{73}$ These two standards encourage member states to substantially improve data quality, statistics and data disclosure. ${ }^{74}$

The problem with the transparency objective consists less in the availability of adequate transparency guidelines than in the willingness to publish the IMF's conclusive reports. In the past, the IMF often did not disclose its findings due to concerns that publishing the data could jeopardise the interests of the country concerned. ${ }^{75}$ Over the last few years, however, the situation has improved: according to the IMF, as of September 2011, eighty-eight countries had completed an assessment of transparency in either monetary policies, financial policies, or both, in the context of an FSAP; furthermore, fifty-seven countries' ROSCs have been published on the IMF website. ${ }^{76}$

Other elements could impede transparency, namely the not always acknowledged functional, operational and economic independence of the central bank as well as the vague limitations of regulatory powers. ${ }^{77}$

\section{World Bank Group}

Starting in the 1990s, the World Bank sponsored the establishment of a worldwide database containing regulatory provisions and practices

${ }^{71}$ See Weber, 'Financial Stability', p. 8.

72 IMF, Special Data Dissemination Standard (March 1996).

73 IMF, General Data Dissemination System (December 1997).

${ }^{74}$ For more details, see Arner, Financial Stability, Economic Growth, and the Role of Law, pp. 132-3.

75 Weber, 'Financial Stability', p. 7 and Arner, Financial Stability, Economic Growth and the Rule of Law, at p. 131.

${ }^{76}$ IMF, Factsheet: Transparency in Monetary and Financial Policies, www.imf.org/exter $\mathrm{nal} / \mathrm{np} / \mathrm{exr} /$ facts/mtransp.htm. On this issue, see also N. Rendak, 'Monitoring and Surveillance of the International Monetary System - What Can Be Learnt from the Trade Field?', Chapter 9, this volume.

77 R. M. Lastra, Legal Foundations of International Monetary Stability (Oxford University Press, 2006), pp. 44-6. 
relevant to banking activities. The survey is very thorough and encompasses the banking regulations of more than 150 countries. Important aspects are the accounting practice, the external auditing and the financial statement transparency as well as the external ratings and the creditors' monitoring. The details are expressed in the form of variables that measure the extent of effectiveness or strength of a given entity in the different practices and enable comparisons across the countries. ${ }^{78}$

The World Bank Group has also emphasised its concerns about transparency by publishing a set of decisions issued by the World Bank Group's Sanctions Board. The disclosed cases concern alleged fraud and corruption and mark a step towards more openness and accountability in the field of anti-corruption. ${ }^{79}$

Furthermore, the World Bank Group, in collaboration with the International Finance Cooperation (IFC), published a guide called 'Doing Business 2012: Doing Business in a More Transparent World ${ }^{80}$ The Report benchmarks the regulations that enhance business activities and those that constrain them, providing quantitative indicators on business regulations; the general comments are illustrated with case studies.

\section{European Central Bank}

In the past, central banks were notorious for being inscrutable, as reflected in Alan Greenspan's famous quip that if you understood what I just said, you must not have heard me correctly'. More recently, the situation has changed and central banks are increasingly trying to improve clarity in explaining their objectives and decisions to the public.

The European Central Bank (ECB) periodically publishes its monetary policy strategy and communicates its regular assessment of economic developments in order to help the markets to understand the systematic response patterns of monetary policy; such transparency makes policy adjustments more predictable for the markets over the medium term. ${ }^{81}$

78 R. H. Weber, Shaping Internet Governance: Regulatory Challenges (Zurich: Schulthess, 2009), p. 126.

79 See World Bank Press Release No. 2012/481/EXT of 30 May 2012.

${ }^{80}$ See www.doingbusiness.org/reports/global-reports/doing-business-2012.

${ }^{81}$ European Central Bank, Eurosystem, www.ecb.int/ecb/orga/transparency/html/index. en.html. 
The improvement of transparency of the ECB also is a political theme: the Directorate General for Internal Policies of the European Parliament, Section on Economic and Monetary Affairs, prepared a document entitled 'Improving ECB's Accountability and Transparency', requesting further-reaching transparency of the ECB in September 2009. ${ }^{82}$ The objective of this initiative is to transform the present 'Monetary Dialogue' with the ECB President into a 'Monetary Hearing'. However, such an approach requires a careful assessment with a view to central bank independence. The debate has recently been taken up again by members of the ECB's Governing Council who are calling for the release of the Council's meeting records. ${ }^{83}$

\section{Basel Committee on Banking Supervision and Financial Stability Board}

The Basel Committee on Banking Supervision (BCBS) realised enhancements, including with regard to transparency issues, to the Basel II capital framework in the reform package Basel III which was formally accepted in September $2010 .^{84}$ The regulations and guidelines prepared by the BCBS, however, concern the financial markets in general, not monetary affairs in particular.

The Financial Stability Board (FSB) has put considerable emphasis on transparency objectives and has taken steps to encourage improved disclosures. In March 2011, the FSB presented a 'Thematic Review on Risk Disclosure Practices' addressing general transparency standards and disclosure requirements under Basel III; the practices are analysed and initiatives that are needed to keep risk disclosures relevant and useful in the future are discussed in detail. ${ }^{85}$ In March 2012, the FSB organised a Round Table on Risk Disclosure, which provided the possibility for a debate about the key themes of transparency; the respective disclosure requirements mainly concern financial regulation related to market participants and touch less upon monetary affairs. ${ }^{86}$

82 See www.europarl.europa.eu/document/activities/cont/200909/20090923ATT61084/20 090923ATT61084EN.pdf.

${ }^{83}$ See below note 124 and accompanying text.

${ }^{84}$ Bank for International Settlements, Basel III: A Global Regulatory Framework for More Resilient Banks and Banking Systems, revised version (June 2011).

85 FSB, Thematic Review on Risk Disclosure Practices, Peer Review Report (18 March 2011) www.financialstabilityboard.org/publications/r_110318.pdf.

86 FSB, Press Release, 20 March 2012, www.financialstabilityboard.org/press/pr_120320.pdf. 


\section{World Trade Organization}

Transparency rules are well known in the World Trade Organization (WTO), notably in the General Agreement on Tariffs and Trade (GATT), the General Agreement on Trade in Services (GATS), which addresses financial services, the Agreement on Technical Barriers to Trade (TBT) and the Agreement on Trade-Related Aspects of Intellectual Property Rights (TRIPS Agreement). ${ }^{87}$ Article X GATS, which is of specific relevance here, attempts to achieve two transparency objectives: on the one hand, transparency is seen as a tool to prevent unnecessary barriers to trade by letting market participants know in advance what requirements would apply in international services trade. In this respect, transparency contributes to a predictable trade environment. On the other hand, transparency contributes to clear decision-making processes and thereby to legitimacy in democratic societies. $^{88}$

The purpose of the transparency provisions is to provide a greater degree of clarity, predictability and information about regulations; the transparency achieved should facilitate the entry of WTO members into the cross-border trade of goods and services based on predictable trade regulations. ${ }^{89}$ Transparent regulation is a core requirement for attracting investment and promoting economic growth; the WTO experiences demonstrate that transparency helps to overcome uncertainties in business processes and to improve the general basis for cooperation. ${ }^{90}$ While trade statistics published by the WTO contain important information for market and policy-makers, its regulatory focus is - in contrast to financial organisations - not on quantitative indicators, but on transparent procedures.

\section{Preliminary assessment}

The analysis of the transparency discussions in international fora during the last five years has shown that this issue has played a key role and that politicians, regulators and expert bodies, among others, were addressing

87 T. Cottier and M. Oesch, International Trade Regulation (Berne: Cameron May/ Staempfli, 2005), pp. 542-51 discuss transparency in the WTO as an element of the rule of law.

${ }^{88}$ Kaufmann and Weber, 'The Role of Transparency in Financial Regulation', p. 795; M. Krajewski, 'Democratic Legitimacy and Constitutional Perspectives of WTO Law', Journal of World Trade 35 (2001), 167-86, 169-70.

${ }^{89}$ See Weber, Shaping Internet Governance, pp. 124-5. ${ }^{90}$ See ibid., p. 125. 
many facets of transparency. In particular, the G-20 assigned a high priority to looking at transparency from various angles.

However, apart from transparency regulations governing (private) banks and other financial institutions or intermediaries, the global community paid hardly any attention to transparency issues in the monetary framework. Under the auspices of the IMF and the World Bank Group, efforts have now been made to improve the level of transparency related to the monetary policies of the respective members, among others. Nevertheless, the main achievement consists in the collection of general data. However, as for the specific needs of transparency in monetary affairs, there are still substantial analytical gaps. The following section attempts to enrich the discussions in other areas for monetary affairs.

\section{The three pillars of transparency in monetary affairs}

\section{Overview: conceptual framework and indicators}

From a legal perspective, transparency can be analysed by applying a three-dimensional concept, as indicated above. The three pillars are (i) institutional procedures and decision-making, (ii) substantive foundation and (iii) accountability. Applying this concept to empirical studies requires a comprehensive set of indicators, which has been developed by Eijffinger and Geraats. ${ }^{91}$ They advocate fifteen indicators for political, economic, procedural, policy and operational transparency: the focus of political transparency is on policy objectives; that of economic transparency is on economic information, such as data, models and forecasts, used for monetary policy; procedural transparency relates to the way decisions are taken; policy transparency means prompt disclosure of policy decisions, together with an explanation of the decision, and an explicit policy inclination or indication of likely future policy actions; operational transparency applies to the implementation of monetary policy. It requires a discussion of the factors, including disturbances, that affect the transmission of monetary policy.

In Table 18.1 we situate Eijffinger's and Geraats' economic indicators (1) to (15) in the legal framework by aligning each indicator with one of the three pillars. In fact, Eijffinger and Geraats define transparency of monetary policy as the extent to which central banks disclose information that is related to the policy-making process. ${ }^{92}$ Consequently, most of

\footnotetext{
${ }^{91}$ Supra note 33. $\quad{ }^{92}$ Eijffinger and Geraats, 'How Transparent are Central Banks?', 3.
} 
the indicators, namely (4)-(6) and (8)-(15), reflect the different stages of the decision-making process and only indicators (1)-(3) refer to the institutional environment. With this focus it is possible to apply quantitative indicators to measure some aspects of monetary transparency. Despite this limited focus, the most recent study by Dincer and Eichengreen shows a correlation between greater transparency of central bank operations with more stable political systems and a higher ranking with regard to the rule of law. ${ }^{93}$ With these empirical findings in mind we will discuss the three-pillar framework in the context of monetary affairs. ${ }^{94}$

\section{The first pillar: institutional framework and decision-making}

\section{Institutional framework}

Legal certainty and predictability are essential for creating a stable environment and are thus a prerequisite for efficient monetary policies. ${ }^{95}$ What has been framed as 'political transparency' by economists, ${ }^{96}$ reflected in indicators (1)-(3) in Table 18.1, refers to key elements of the rule of law: the applicable rules must be published, communicated and made accessible to the addressees of the regulations. ${ }^{97}$ As simple as this may sound in theory, in practice, its implementation can be challenging. Empirical studies show that institutional transparency ranks high among the various dimensions of central bank transparency. ${ }^{98}$

Indicators for measuring institutional transparency are formal statements of the objectives of monetary policy combined with a quantification of these objectives as well as explicit contracts or other institutional arrangements between monetary authorities and the government. ${ }^{99}$

The institutional arrangements required for efficient monetary policymaking show some similarities with the transparency requirements under WTO law with regard to publishing trade-related regulations and restrictions. From an economic perspective, the rationale is the same: enhancing efficiency and facilitating business activities. Market

93 Dincer and Eichengreen, 'Central Bank Transparency', 85.

${ }^{94}$ For a recent general description of legal and economic elements of monetary affairs (without aspects of transparency), see P. Nobel and H. Zimmermann, 'Money, Legally and Economically Speaking', in P. Nobel and R. Benevenuto (eds.), Law and Economics of Money and Currency (Zurich: Schulthess, 2012), p. $1 \mathrm{ff}$.

95 Kaufmann and Weber, 'The Role of Transparency in Financial Regulation', 784.

96 Dincer and Eichengreen, 'Central Bank Transparency', 81-3.

97 See also Kaufmann and Weber, 'The Role of Transparency in Financial Regulation', 784.

98 Dincer and Eichengreen, 'Central Bank Transparency', 82. 99 Ibid., 92; Table 18.1. 
Table 18.1. Monetary transparency: indicators and conceptual framework

Legal concept (Kaufmann and Weber 2010)

Economic

indicators

(Eijffinger and Institutional procedures and

Geraats 2006) decision-making

Substantive foundation

Accountability

\begin{tabular}{cc}
\hline $\begin{array}{c}\text { Political } \\
\text { transparency }\end{array}$ & $\begin{array}{l}\text { (3) Are there explicit contracts or } \\
\text { other similar institutional } \\
\text { arrangements between the } \\
\text { monetary authorities and the } \\
\text { government? }\end{array}$ \\
&
\end{tabular}

(1) Is there a formal statement of the objective(s) of monetary policy, with an explicit prioritisation in case of multiple objectives?

(2) Is there a quantification of the primary objective(s)?

transparency

Procedural

transparency
(7) Does the central bank provide an explicit policy rule or strategy that describes its monetary policy framework?
(4) Is the basic economic data relevant for the conduct of monetary policy publicly available?

(5) Does the central bank disclose the formal macroeconomic model(s) it uses for policy analysis?

(6) Does the central bank regularly publish its own macroeconomic forecasts?

(8) Does the central bank give a comprehensive account of policy deliberations (or explanations in case of a single central banker) within a reasonable amount of time?

(9) Does the central bank disclose how each decision on the level of 
Policy

transparency

Operational

transparency its main operating instrument or target was reached?

(10) Are decisions about adjustments to the main operating instrument or target announced promptly?

(11) Does the central bank provide an explanation when it

announces policy decisions?

(12) Does the central bank disclose an explicit policy inclination after every policy meeting, or an

explicit indication of likely future policy actions (at least quarterly)?

(13) Does the central bank regularly evaluate to what extent its main operating targets (if any) have been achieved?

(14) Does the central bank regularly provide information on

(unanticipated) macroeconomic disturbances that affect the policy transmission process?

(15) Does the central bank regularly provide an evaluation of the policy outcome in light of its macroeconomic objectives? 
participants need to know the applicable rules. From a legal perspective, transparency of the institutional framework follows from the rule of law.

A further important element related to the institutional pillar is the independence of monetary institutions from governmental influence. ${ }^{100}$ This independence is closely related to the above-mentioned need to learn about the economic environment and the discretion to deviate from announced policies based on new knowledge, if necessary. Nevertheless, the delegation of policy decisions and reactions to a changing environment to independent central banks or to other monetary institutions, requires democratic safeguards. These institutions need to be vested with the necessary legitimacy both politically and democratically. In this regard, communicating experiences and knowledge, as well as lack of knowledge, to society and thus making policy changes and the underlying 'learning process' transparent, is essential. ${ }^{101}$ Such transparency requirements do not preclude measures such as market interventions which cannot be communicated in advance if they are to remain effective. What transparency requires in such circumstances is a timely ex post communication about the assessment of the situation by the central bank that led to the measures being taken as well as an evaluation of (the 'lessons learnt' from) the achieved results.

\section{Procedural transparency}

Related to the institutional framework is procedural transparency in terms of a clear allocation of tasks and responsibilities to authorities and the market participants, respectively. Members of society must be able to establish who is doing what under which circumstances and who can be approached and reproached. ${ }^{102}$ Uncertainty with respect to responsibilities and procedures should be avoided. This criterion is (partially) reflected in indicator (3) in Table 18.1.

An example of non-transparent policy goals and uncoordinated standards occurred in Switzerland in summer 2012: notwithstanding the fact that Credit Suisse is permanently supervised by FINMA, the

${ }^{100}$ K. Hielscher and G. Markwardt, 'The Role of Political Institutions for the Effectiveness of Central Bank Independence', European Journal of Political Economy 28 (2012), 286-301.

101 King, 'The Institutions of Monetary Policy', 5-6 and 12: 'A central bank needs to explain to the population both what it knows and what it does not know.'

102 See also the similar question raised by Kaufmann and Weber, 'The Role of Transparency in Financial Regulation', 785. 
Swiss financial market supervisory authority, the Swiss National Bank (SNB), published a statement (without having properly pre-informed Credit Suisse) that in its view Credit Suisse was substantially undercapitalised. While it was undisputed that Credit Suisse, as well as other banks, needed to increase its capital base, FINMA as the competent supervisor had granted an implementation period until 2019. ${ }^{103}$ Not surprisingly, the SNB's statement triggered market turbulence. Obviously, contradictory statements of FINMA and the SNB created uncertainties in the market and thereby jeopardised transparency of the current analysis of facts by different public agencies.

\section{The second pillar: substantive foundation}

The Atlantic Charter signed by Franklin D. Roosevelt and Winston Churchill in August 1941, and the subsequent negotiations at the Bretton Woods Conference in 1944, emphasised what is broadly accepted today: transparency is not a goal in itself but rather a means to an end. In fact, the negotiators at Bretton Woods agreed that stable monetary and financial systems were a key condition for a peaceful postwar order. ${ }^{104}$ Transparency was seen as a catalyst for re-establishing trust in stable currencies after the turmoil of the 1930s. ${ }^{105}$ The means of achieving the desired objectives was the establishment of the IMF and the World Bank and a fixed exchange rates regime tied to gold.

Still, the important criterion is not the quantity of information but its quality. As pointed out above in Section C, many institutions have become involved in standard-setting and regulation in the aftermath of the financial crisis. In increasingly interconnected financial markets, proposals for regulation and the responses by different stakeholders tend to multiply among the different fora and at the national and international level. ${ }^{106}$

It seems that in the global quest for transparency, the need for goodquality information rather than information overload has been partially neglected, not only as far as the regulation of financial markets in general

103 FINMA Newsletter 38 (2012), 20 July 2012, Eigenmittelnachweis - Basel III (German only), www.finma.ch/e/finma/publikationen/Pages/finmamitteilungen.aspx.

104 See Weber and Arner, 'Toward a New Design', $393 \mathrm{ff}$.

105 See Kaufmann and Weber, 'The Role of Transparency in Financial Regulation', 787.

106 Bradley, 'Transparency is the New Opacity', 28. 
is concerned, ${ }^{107}$ but also in monetary affairs. ${ }^{108}$ In fact, information overload may make it impossible to adequately process, digest and use the information ${ }^{109}$ and can lead to the so-called 'Cassandra effect" ${ }^{\text {'10 }}$ or to ignoring 'the prospect of future changes about the actual character of which we know nothing. ${ }^{11}$

In essence, the impact of transparency measures on public policy depends on their structure and on the balance between the 'value of sunlight' and 'over-exposure'. The latter may result in information overload, excessive politicisation or dysfunctional surveillance. ${ }^{112}$ In addition, consumers may be overwhelmed with information which may hamper their ability to make informed good decisions. ${ }^{113}$ As Caroline Bradley noted, complex transactions lead to complex rules and standards and this complexity impedes transparency. At the same time, efforts to make transnational standard-setting processes more transparent risk making the information overload problem worse rather than better. ${ }^{114}$

Generally speaking, any policies for enhancing transparency require not only a solid conceptual basis but also a substantial relation to the purpose for which the information is sought, to the capacity of and the incentives for actors to provide the information. ${ }^{115}$ If different organisations and supervisory bodies for financial markets succeed in clarifying the content of tasks as well as the regulatory responsibility and transparency, the confidence of market participants will increase. ${ }^{116}$ Moreover, apart from their substantial value, clearly defined mandates

107 The Sarbanes-Oxley Act of 30 July 2002, 116 Stat. 745, 15 USC $\$ 7201$ is a good example of an extremely detailed (and complicated) 'rule book' which, however, does not allow the addressees of the rules to gain easy 'access' to the basic underlying message of the detailed regulations.

108 Bradley, 'Transparency is the New Opacity', 28-32.

109 D. Heald, 'Varieties of Transparency', Proceedings of the British Academy 135 (2006), $25-43,35$.

${ }^{110}$ For further details, see R. H. Weber, 'Kassandra oder Wissensbroker - Dilemma im Global Village', in J. Becker, R. M. Hilty, J.-F. Stöckli and T. Würtenberger (eds.), Recht im Wandel seines sozialen und technologischen Umfelds, Festschrift für Manfred Rehbinder (Bern: Stämpfli, 2002), pp. 405-21, 407.

111 J. M. Keynes, 'The General Theory of Employment', Quarterly Journal of Economics 51 (1937), 209-23, 214.

112 Heald, 'Why is Transparency About Public Expenditure So Elusive?', 32.

113 Bradley, 'Transparency is the New Opacity', 28. ${ }^{114}$ Ibid., 31.

115 See Kaufmann and Weber, 'The Role of Transparency in Financial Regulation', 790; R. B. Mitchell, 'Sources of Transparency: Information Systems in International Regimes', International Studies Quarterly 42 (1998), 109-30, 109-10.

116 See Kaufmann and Weber, 'The Role of Transparency in Financial Regulation', 790. 
and tasks are important elements of accountability which, as indicated in Table $18.1,{ }^{117}$ is a key criterion in shaping efficient monetary policies.

\section{The third pillar: accountability}

Accountability is a concept with many facets: ${ }^{118}$ together with checks and balances it is a prerequisite for legitimacy and a key element of any governance discussion. Obviously, accountability depends on reliable information. ${ }^{119}$

Accountability must be assessed with regard to the manifold relationships in the financial sector, in particular between the state and the financial institutions, between supervisory authorities and market participants and between different (quasi-) governmental organisations. ${ }^{120}$ These relationships should be based on a transparent data regime: ex ante mechanisms help to prevent the abuse of power, ex post accountability applies instruments such as a judicial review or non-traditional remedies to assess monetary activities. ${ }^{121}$ Indicators (2)-(6) in Table 18.1 focus on measures to make information on the policy framework accessible and are therefore related to ex ante accountability, while indicators (8)-(15) focus on ex post assessments.

In addition, a distinction needs to be made between a retrospective reporting cycle and real-time surveillance. The key difference between the two lies in the length of the accountability window. In a real-time setting, the accountability window is always open and surveillance is an ongoing process. Examples of this type of system are macroeconomic forecasts, including changes. In a retrospective system, the accountability window will be interrupted by the reporting lag during which the institution is preparing the information for the public. ${ }^{122}$ Retrospective transparency may prevent political pressure on central bank board members when it comes to disclosing the minutes of board meetings.

117 Above Section D.I; Dincer and Eichengreen, 'Central Bank Transparency', 88.

118 R. M. Lastra and H. Shams, 'Public Accountability in the Financial Sector' in E. Ferran and C. Goodhart (eds.), Regulating Financial Services and Markets in the 21st Century (Oxford University Press, 2001), pp. 165-88, 166-9; Weber, Shaping Internet Governance, p. 133.

119 Kaufmann and Weber, 'The Role of Transparency in Financial Regulation', 791.

120 See also ibid., 791.

121 R.W. Grant and R. O. Keohane, 'Accountability and Abuses of Power in World Politics', American Political Science Review 99 (2005), 29-43, 30-1; slightly different, Lastra and Shams, 'Public Accountability', p. 169.

${ }^{122}$ Heald, 'Why is Transparency About Public Expenditure So Elusive?', 32-4. 
An example of a retrospective system is the proceedings of the Federal Open Markets Committee of the Federal Reserve, which are released with a delay of one month. ${ }^{123}$ In contrast, the European Central Bank has, since its establishment, justified its refusal to publish the minutes and voting records of its council on the grounds that individual members would then be subject to pressure from special interest groups (national interests, in this context) that might compromise their independence and lead to inefficient policy decisions. Recently, this policy has become controversial with at least two members of the ECB's Governing Council advocating increased transparency, by, inter alia, releasing the minutes of the meetings. ${ }^{124}$ A possible middle-way could be to publish voting patterns instead of individual council member statements, which may foster predictability while still protecting independence. ${ }^{125}$

Clearly, in a monetary context, reliable quantitative indicators for communicating and evaluating monetary objectives, such as inflation targets, are essential for establishing credible accountability mechanisms. Recent empirical studies suggest a positive correlation between transparent accountability mechanisms as captured by indicators (8)-(15) in Table 18.1 and lower inflation rates. ${ }^{126}$

\section{E. Conclusions}

This chapter shows that the present lack of a comprehensive analytical framework for transparency in monetary affairs can at least partially be compensated by adapting existing instruments available in other areas of law. We suggest complementing the general three-pillar framework institutional and/or procedural elements, substantive foundation and accountability - with criteria that are empirically proven to enhance efficiency of monetary policy. Examples include the fifteen indicators developed by Eijffinger and Geraats ${ }^{127}$ which are highly relevant for our framework as shown in Table 18.1.

123 Federal Open Market Committee - Statements of Policy, Policy Regarding the Government in the Sunshine Act, 12 CFR 281; as amended effective 16 February 2005.

124 'Making the European Central Bank more Transparent', Financial Times, 19 September 2012; 'Wie viel Transparenz verträgt die EZB?', Neue Zürcher Zeitung, 20 September 2012, 25.

125 P.M. Geraats, 'ECB Credibility and Transparency', European Economy, Economic Papers 3330 (European Commission, June 2008), p. 25.

126 Dincer and Eichengreen, 'Central Bank Transparency', 90.

127 Eijffinger and Geraats, 'How Transparent are Central Banks?'. 
As for procedural transparency, lessons can be drawn from WTO law, in particular the GATS, with its strong emphasis on the rule of law. This approach is supported by empirical findings according to which a stronger adherence to the rule of law is correlated to higher transparency. Moreover, transparency is particularly relevant for the publication of monetary policy and related instruments as reflected in indicators (1), (3)-(6), (8)-(9) and (13)-(15) in Table 18.1.

Since transparency in monetary affairs requires quantitative, measurable criteria, transparency indicators, such as those established by the IMF, should be included and elaborated further to meet the specific needs of monetary policy.

Finally, we conclude that, in monetary affairs, striking a balance between transparency and other policy goals is necessary. Recent debates illustrate that enhanced transparency may lead to increased political pressure and thus jeopardise central bank independence. In our view, the parameters for such a balancing test should be defined in a democratically legitimised process. 